\title{
The role of customers in the gig economy: how perceptions of working conditions and service quality influence the use and recommendation of food delivery services
}

\author{
Daniel Belanche ${ }^{1} \cdot$ Luis V. Casaló $^{2} \cdot$ Carlos Flavián $^{3}$ (D) Alfredo Pérez-Rueda ${ }^{4}$
}

Received: 11 March 2020 / Accepted: 15 December 2020 / Published online: 5 February 2021

(C) The Author(s), under exclusive licence to Springer-Verlag GmbH, DE part of Springer Nature 2021

\begin{abstract}
This research examines how customers' perceptions about controversial labor practices of food delivery platforms may affect their intentions to use and recommend these services. Three studies reveal that customers' behavioral intentions depend on their perceptions of the working conditions for the delivery workers, as well as service quality. This influence is higher among customers with a high level of social conscious consumption. Our research also explores the costs that customers would be willing to assume to be served by a food delivery service that offers better working conditions. These insights reveal several relevant managerial implications for gig economy firms.
\end{abstract}

Keywords Food delivery · Gig economy · Working conditions · E-S-QUAL · Social consciousness

Carlos Flavián

cflavian@unizar.es

Daniel Belanche

belan@unizar.es

Luis V. Casaló

lcasalo@unizar.es

Alfredo Pérez-Rueda

aperu@unizar.es

1 Department of Marketing and Market Research, Faculty of Economy and Business, University of Zaragoza, Zaragoza, Spain

2 Department of Marketing and Market Research, Faculty of Business and Public Management, University of Zaragoza, Huesca, Spain

3 Department of Marketing and Market Research, Faculty of Economy and Business, University of Zaragoza, Zaragoza, Spain

4 Department of Management, Faculty of Social and Labor Sciences, University of Zaragoza, Zaragoza, Spain 


\section{Introduction}

Enabled by digital platforms such as Uber or Deliveroo, services of the gig economy have transformed business models and already account for an increasing proportion of the economy (Burtch et al. 2018; Lee and Lee 2020). The gig economy defines workforce exchanges as "people using apps (online platforms) to sell their labor" (Taylor et al. 2017, p. 23). Advanced information technologies and contemporary capitalism encourage such gig or transaction-based jobs, for which the "employee" is hired globally by an online platform but the work is delivered locally (Goods et al. 2019; Huws et al. 2016; Wood et al. 2019). A prototypical service business of the gig economy is platform-based food delivery. Companies in this sector have achieved an estimated value of US $\$ 94,385$ million, and predicted revenues appear likely to grow by $9.3 \%$ annually over the next few years (Statista 2019). They are already emerging as an essential business model for U.S. and Chinese restaurants (Cho et al. 2019), and their global impact has been strengthened during the COVID-19 crisis (Spurk and Straub 2020).

Along with this growth though, substantial controversy has arisen regarding the labor conditions and employment standards in the gig economy (Kaine and Josserand 2019; Stewart and Stanford 2017). Veen et al. (2019) describe some key elements distinguishing the labor practices of food delivery platforms from traditional employers. First, gig economy firms exert more control over workers through their technological infrastructure, which monitors workers in real time and creates a state of vigilance. Second, gig economy firms deliberately create information asymmetries (e.g., hidden delivery addresses) to reduce workers' ability to make decisions. Third, the platform management systems are based on algorithms that function as control barriers and limit workers' understanding of the decisions. In some cases, delivery people must pay their own maintenance costs and risk unsafe working conditions (Garijo and Requena 2016).

As far as the gig economy challenges labor practices but also consumption decisions (Healy et al. 2017), our research investigates customers' concern about the labor practices of platforms in the gig economy and its impact on their consumption decision making. More precisely, we analyze the extent to which customers' perceptions of delivery people's working conditions influence their decisions to use and recommend the food delivery service. Previous evidence suggests that consumers may worry about these delivery employees and the poor working conditions they encounter (Romera and Semprún 2018), though there is a lack of research insights into the impact of working conditions on customers' reactions to a firm that employs delivery people in such conditions. To further advance on the understanding of this phenomenon from a customer approach, we also propose that customers' traits (i.e., social consciousness) may be crucial to consider the working conditions of the gig workers when deciding about the use and recommendation of food delivery services. Thus, in line with socially conscious consumption predictions (e.g., fair trade, Pepper et al. 2011; Rashid and Byun 2018), we further propose that improving the working conditions for delivery drivers may be particularly effective among socially conscious costumers. 
Labor scholars note the need for research into the controversial labor practices of the gig economy, but they did not account for the role of customers on this issue (Healy et al. 2017; Kaine and Josserand 2019). In turn, services and marketing studies of customers' perceptions about platform-based services tend to highlight their advantages, determining that these platforms are used mostly because of practical and hedonic reasons (Cho et al. 2019; Lee et al. 2019; Ray et al. 2019; Yeo et al. 2017). When analyzing the factors discouraging the use of food delivery services, previous studies have focused on the traditional barriers that are concomitant to e-services such as customers' security concerns (Belanche et al. 2020b) and lack of trust (Cho et al. 2019), largely ignoring any critical perspectives on the new features of these business models and their laborrelated practices.

Thus, our proposal provides a novel approach to assess customers' loyalty to food delivery. To the best of our knowledge, this research offers the first investigation of customers' perceptions of the working conditions of gig economy workers and their potential influences on using and recommending behaviors. To better assess the influence of working conditions on customers' decisions, we also account for service quality as a baseline framework and counterbalancing factor that may motivate users' preference for these services. Studies pertaining to people-technology interactions suggest that customers evaluate service technologies according to their existing beliefs and experience (Ju et al. 2019; Lien et al. 2017; Parasuraman 2000), as manifested in service quality perceptions. They are critical success factors for customer-oriented delivery businesses (Collier and Bienstock 2006; Parasuraman et al. 1988), which requires a system that ensures flawless delivery. In particular, we focus on the Electronic Service Quality (E-S-QUAL) model (Parasuraman 2000), which offers an integrated framework for evaluating customers' perceptions of system-level service quality, according to four main dimensions (efficiency, fulfillment, system availability and privacy).

This research contributes to the service field in three domains. First, our study contributes to a better understanding of the gig economy phenomenon as a new and fast growing business model in services, and the food delivery sector in particular, as it relates to working conditions for delivery drivers, which constitute a social issue of increasing public concern. Second, Study 1 explores whether working conditions of food delivery employees and online service quality factors, as established in other technological contexts, are both relevant to the case of food delivery services. Third, our research delves into the practical implications for the industry by means of two experimental designs. Study 2 considers how improving the working conditions of food delivery employees might influence customers' intentions to use and recommend the services, as well as the extent to which socially conscious customers (i.e., a customer trait enabling segmentation strategies) might be particularly affected by changes in these working conditions. Study 3 analyzes whether customers are willing to take on extra costs (e.g., wait longer, pay a premium) to be served by a company with improved working conditions. The concluding section discuss these findings and their managerial implications. 


\section{Literature review}

\subsection{The food delivery phenomenon}

As customers increasingly purchase through the Internet (Chiang and Dholakia 2003; Mehmood and Najmi 2017), transactions are becoming to be carried out by untact services (Lee and Lee 2020). In particular, home delivery services have emerged as an easy, convenient choice that help customers receive products at the right time and place, in the right quantity, and in the right condition (Chen et al. 2014; Mehmood and Najmi 2017). For example, food delivery services, by which a food distributor functions as an intermediary between restaurants and customers (Cho et al. 2019), have embraced a business model that leverages the advantages of the Internet, including the technological capability to connect different agents of the distribution process efficiently. Online food delivery companies specialize in prepared food distribution, with processes for receiving orders from customers, sending them to restaurants, and notifying self-employed gig workers to pick up the food from restaurants and deliver it to customers. The requests for service might come through the Internet via web pages or, more frequently, mobile applications, being these technologies critical facilitators of the food delivery process (Cho et al. 2019). They make it easy for customers to insert the delivery address, select the local restaurant and food options, add products to a shopping cart, make payments, and track the status of the order.

In this sense, convenience motivations (e.g., time and cost savings) appear to be primary drivers of customers' behavioral intentions toward food delivery services (Yeo et al. 2017). Ray et al. (2019) and Belanche et al. (2020b) note that, in addition to experience and convenience motivations, customers are influenced by societal pressures, as a kind of subjective norm. The possibility to order various food choices has been pointed out as a factor motivating customers to use food delivery services (Cho et al. 2019). In turn, some studies found that customers' hedonic motivations may be also encouraging them to order food online as an enjoyable purchase (Lee et al. 2019; Yeo et al. 2017). From a complementary approach, previous research found that price, as an economic factor, also determines loyalty to food delivery services (Cho et al. 2019; Lee et al. 2019).

However, previous research on food delivery services in the gig economy has not covered how customers' perceptions of service quality or the working conditions for delivery personnel might motivate or inhibit their decisions to adopt the services.

\subsection{Theoretical background}

\subsubsection{E-S-QUAL model of food delivery services}

As noted, food delivery services are a relatively new market that is growing rapidly and globally (Cho et al. 2019). On online platforms, companies engage in intense competition to provide users with faultless service quality. Thus, from both 
theoretical and empirical perspectives, service quality should be a central determinant of users' intentions toward firms. The SERVQUAL (service quality) framework, describes service quality as "an abstract and elusive construct because of the three features unique to services: intangibility, heterogeneity, and inseparability of production and consumption" (Parasuraman et al. 1988, p. 13). In the offline setting, the scale consisted of 22 items belonging to five dimensions: tangibles (e.g., physical facilities), reliability (performance), responsiveness (prompt service), assurance (e.g., knowledge and courtesy of employees), and empathy (individual attention).

Following the advent of the Internet, several authors proposed new frameworks to better assess service quality in the online context. WebQual (Loiacono et al. 2002) was introduced as an instrument to rate web sites design. Nevertheless, although some of the WebQual dimensions influenced perceived service quality from a technical approach, other important dimensions, such as customer service, were ignored (Parasuraman et al. 2005). Szymanski and Hise (2000) developed a framework to assess customer perceptions regarding online convenience, merchandising, site design, and financial security. However, the scale focused on satisfaction rather than service quality (Parasuraman et al. 2005). Yoo and Donthu (2001) and Barnes and Vidgen (2002) also tried to measure website quality from alternative approaches but these scales just focused on specific quality aspects (e.g., service offerings) and did not capture all aspects of the purchasing process. All these studies provided interesting insights for evaluating online service quality, but they did not provide valuable instruments fully able to evaluate service quality (Parasuraman et al. 2005).

In this context, the authors of the SERVQUAL introduced an E-S-QUAL framework to assess the quality of online sales interactions (Parasuraman et al. 2005). They define e-service quality as the "extent to which a website facilitates efficient and effective shopping, purchasing, and delivery" (Parasuraman et al. 2005, p. 5). E-S-QUAL is operationalized as a second-order construct comprising four dimensions: efficiency, fulfillment, system availability, and privacy (Zeithaml 2002; Parasuraman et al. 2005). Currently, it represents the leading framework used to measure the quality of online services (Belanche et al. 2014; Blut et al. 2015).

Efficiency implies that the web page functions simply and quickly when accessed, so that consumers can search for specific products, rather than browse (Kim et al. 2006). An easily structured system that requires a minimum information to be input by the customer will be described as efficient, increasing users' willingness to use it in order to improve their performance (Zeithaml 2002). Fulfillment is the extent to which the online service is reliable in its functioning and product presentation. It deals with aspects such as the timeliness of the delivery, the order accuracy and the delivery condition (Blut et al. 2015). Previous literature shows that fulfillment has significant impacts on consumer evaluations of online services in retail settings because users prefer to use services that meet with their promises (Trocchia and Janda 2003; Wolfinbarger and Gilly 2003). System availability entails the correct technical functioning of the website or app, such that malfunctions of the online platform may have significant negative influences on consumers' quality perceptions (Kim et al. 2006; Santos 2003). System availability is also related to the compatibility between the customer and service provider technology, such as the match between the smartphone and the mobile app (Lien et al. 2017). Thus, system 
availability increases customers' use of an online service because of its accessibility and 24/7 availability compared to other alternatives (Belanche et al. 2014). Finally, privacy refers to the website's security and protection of customer information (Marimon and Cristóbal 2012; Parasuraman et al. 2005). Debates about the importance of privacy for perceptions of online service quality feature some evidence that it does not significantly influence consumers' perceptions (Wolfinbarger and Gilly 2003). However, most studies support the importance of privacy as a factor increasing customers' willingness to rely on online systems (Faqih 2016; Szymanski and Hise 2000), especially in current mobile apps (Joo and Shin 2020).

Overall, while a high service quality perception generally leads to favorable behavioral intentions, low perceived service quality leads to unfavorable ones (Udo et al. 2010). Enhancing the different dimensions of service quality thus should increase customers' intentions to use and recommend a service (Hausman 2003; Zeithaml et al. 1996; Zhang and Prybutok 2005). As a result, we propose that:

H1 E-S-QUAL positively influences intention to use a food delivery service.

H2 E-S-QUAL positively influences intention to recommend a food delivery service.

\subsubsection{Working conditions in the gig economy}

The gig economy entails work transacted through global online platforms but delivered locally (Huws et al. 2016; Wood et al. 2019), which is digitally controlled but also requires a worker to be physically present. This platform-based structure changes the way work is organized (Drahokoupil and Piasna 2019) in that, for many workers, their tasks are planned digitally and they usually are remunerated on a piece-rate basis (De Stefano 2016). The resulting labor conditions offer some advantages for workers, such as labor market flexibility (Mulcahy 2016), but also impose the risk of uncertain incomes and potentially poor working conditions (Stewart and Stanford 2017).

For example, food delivery platforms rely on workers to add value to the service. They promote their available jobs as good opportunities that offer flexibility and complementarity, but they also may create a lack of clarity regarding their labor relationship (Fernández 2017). As Goods et al. (2019) point out, food delivery platforms may vary somewhat in their contractual arrangements, remuneration models, and workers' compensation, but their labor practices exhibit strong similarities: workers $\log$ on to an app to signal their availability. Each customer order prompts the system to allocate the delivery to a driver, through notifications on the app. At that moment, the worker can accept or reject the task, but the only provided information is the address of the restaurant from which they will obtain the order, not the delivery address. This information asymmetry means workers cannot make totally informed decisions. If they accept the order, they go to the restaurant, where they may have to wait if it is not ready. After gathering the ordered items, they learn the delivery address from the system. Drivers get paid only on the basis of their journey to the delivery address, which means their wages are uncertain at the moment 
they choose whether to accept the task (Garijo and Requena 2016). Because they are not remunerated for the time needed to complete overall service, but solely for each delivery made, workers try to deliver as many orders as they can. Many of them use bikes and motorbikes in urban settings, which can create unsafe working conditions (Garijo and Requena 2016). In addition, as self-employed contractors, they must pay their own maintenance costs. Prompted by concerns about this scenario, the Spanish National Court recently ruled that the agreements actually are "false self-employed" contracts and required delivery companies to assume a part of their workers' maintenance expenses (EFE 2020).

Customers likely have grown accustomed to scores of delivery drivers on city streets, and popular media reports highlight the questionable labor conditions of people working for food delivery platforms, especially following specific incidents (e.g., accidents, violence; BBC 2019) or legal challenges to the labor practices (Carman 2019). Such controversies and news reports (Fernández 2017) may nudge consumers to take these issues into account when choosing among food delivery services. In general, consumers tend to humanize frontline employees and feel compassionate toward them. So we predict they also empathize with food delivery workers because of their perception of the drivers as normal people, who may be at risk due to unfair and unsafe working conditions (Tsarenko et al. 2019), earn insufficient remuneration (Azar 2005), or suffer from untenable working conditions (Nickols and Nielsen 2011). Such concerns about working conditions represent social issues (Kim and Jang 2019). Considering these predictions in combination, we anticipate that consumer perceptions of the working conditions for food delivery services affect their intentions to use and recommend the service. If they develop a collective sense of these working conditions, perceptions of better conditions should increase these behavioral intentions (Carrigan et al. 2004). Therefore, we propose that:

H3 Customers' perceptions of better working conditions for food delivery workers positively influence their intention to use the service.

H4 Customers' perceptions of better working conditions for food delivery workers positively influence their intention to recommend the service.

\subsubsection{The influence of intention to use on intention to recommend the service}

Intention to use a product or service commonly comes from the fact that the amount of value received from consuming the product or service is greater than the value of not consuming it (Hallowell 1996). Thus, consumers perceiving this greater value are motivated to use the platform but also to recommend this service (Belanche et al. 2010). Previous literature found a positive relation between use and recommendation because through the recommendation, consumers reinforce their own decision (Zhang et al. 2019). In addition, users tend to spread the message after a successful outcome in order to make other customers aware of the value of such service, acquiring a positive image around the people (Brown et al. 2005; Belanche et al. 2020b). Consequently, we propose that: 
H5 Customers' intention to use the food delivery positively influences their intention to recommend the service.

\section{Study 1}

\subsection{Design and procedure}

To test Hypotheses 1-5, we designed a survey-based study. It includes the variables considered in the theoretical framework, along with price perception as an economic control variable likely determining service use and recommendations (Mohamed et al. 2014; Tascioglu et al. 2019). The questionnaire was presented as a research into food delivery services, carried out by academic research purposes. Participants were recruited via a market research company with a data panel over 70,000 consumers worldwide, which enables us to obtain a diverse sample in terms of nationality and demographics. Of the 500 consumers of food delivery services addressed, 466 decided to participate and completed the questionnaire. Of the final sample, $29.82 \%$ use platform-based food delivery at least once a year, $33.69 \%$ once a moth, $31.97 \%$ once a week, and $4.51 \%$ more than once a week. To a high extent, they reported to "have read, watched or listened some news or information about the working conditions of the food delivery workers (deliverers)" ( $M=4.84$ in a sevenpoint Likert scale, $S D=1.81$ ) and to be "aware of the demands of the food deliverers about their working conditions" $(M=5.04, S D=1.58)$. To confirm the robustness of the hypotheses test across countries, our empirical study focused in two subsamples, 242 Spanish customers and 224 U.S. customers. Table 1 presents the demographics of both subsamples and its representativeness of customers of food delivery in each country.

\subsection{Measurement}

\subsubsection{Measurement instrument}

We measured the variables using seven-point Likert-type scales, with endpoints of $1=$ "totally disagree" and 7= "totally agree." To measure the E-S-QUAL dimensions, we used the scales by Parasuraman et al. (2005), and Marimon and Cristóbal (2012). Regarding the working conditions in the gig economy, we adapted an eightitem scale from Öberseder et al. (2013). The scale from Belanche et al. (2011) provided the measure of intention to use. For intention to recommendation, we used the scale developed by Harrison-Walker (2001). We measured price with the scale developed by Sweeney and Soutar (2001). The Appendix included in Sect. 8 presents all the scales items.

The scales of the questionnaire were administered to each subsample in the native language (i.e., Spanish or English). To ensure that the meanings of the items were understood, a parallel-blind translation process was employed (Lonner and Berry 1986). This process involves a series of back and forth translations of the scale from 
Table 1 Demographics in percentage

\begin{tabular}{lllll}
\hline & $\begin{array}{l}\text { Spain survey } \\
\text { respondents }\end{array}$ & Spain users ${ }^{\mathrm{a}}$ & $\begin{array}{l}\text { U.S. survey } \\
\text { respondents }\end{array}$ & U.S. user $^{\mathrm{b}}$ \\
\hline Gender & & & & \\
Female & 49.17 & 50.00 & 49.11 & 52.20 \\
Male & 50.83 & 50.00 & 50.00 & 47.50 \\
Prefer not to say & 0 & NA & 0.89 & NA \\
Age (years) & & & & \\
18-24 & 16.53 & 16.00 & 22.77 & 20.60 \\
$25-34$ & 37.19 & 44.00 & 33.04 & 31.50 \\
35-44 & 34.30 & 30.00 & 24.11 & 23.60 \\
45-54 & 9.09 & 8.00 & 9.82 & 15.30 \\
Over 54 & 2.89 & 2.00 & 10.27 & 9.00 \\
Education level & & & & NA \\
Primary & 0.41 & NA & 0 & NA \\
Secondary & 23.14 & NA & 27.68 & NA \\
Bachelor's & 59.09 & NA & 41.52 & NA \\
Master & 17.36 & NA & 30.80 & NA \\
Occupation & & & & NA \\
Student & 12.50 & 14.00 & 17.41 & NA \\
Worker & 76.56 & 76.00 & 60.27 & NA \\
Retired & 0 & NA & 3.13 & NA \\
Homemaker & 0 & NA & 4.91 & 12.95 \\
Unemployed & 9.38 & 9.00 & 1.34 & \\
Other & 1.56 & 1.00 & & \\
\hline NA not & & & & \\
\hline
\end{tabular}

$N A$ not available

${ }^{\mathrm{a}}$ Extracted from JustEat (2019)

${ }^{\mathrm{b}}$ Extracted from Statista (2019)

the original language to Spanish language. The scale was first translated by a bilingual professional translator from English to the native language of the sample country and then independently examined by a Spanish assistant fluent in the language. Then, another professional translator back-translated the scale from Spanish into English. Afterward, a third individual compared the back-translated scale with the original scale and verified that the two versions did not differ significantly. Finally, a pretest with the last version of the questionnaire was conducted with 20 graduate and postgraduate Spanish speaking students and a group of five scholars; all of them confirmed that the survey did not present any language difficulty.

\subsubsection{Measurement validation}

To confirm the dimensional structure of the scales, this study performed a confirmatory factor analysis and employed the statistical software EQS 6.1. Specifically, to 
allow for a stringent test of convergent and discriminant validity, we included all reflective constructs in a single confirmatory factor model (Steenkamp and Geyskens 2006). First, we checked whether factor loadings of the confirmatory model were statistically significant (at 0.01) and higher than 0.5 (Steenkamp and Van Trijp 1991; Jöreskog and Sörbom 1993). Two items (i.e., SYS1 and WOR8) needed to be eliminated (see Appendix), and acceptable levels of convergence, $R^{2}$ values, and model fit were obtained $\left[\chi^{2}=1740.984,566 d f, p<0.000 ; \mathrm{NNFI}=0.932 ; \mathrm{CFI}=0.939\right.$; $\mathrm{IFI}=0.940 ; \mathrm{RMSEA}=0.067 ; 90 \%$ confidence interval $(0.063,0.070)]$. To assess construct reliability, this study also checked that values of the composite reliability (CR) indicator (Jöreskog 1971) were above the suggested minimum of 0.65 (Steenkamp and Geyskens 2006), as can be seen in Table 2. To further ensure convergent validity, we also verified that average variance extracted (AVE) values were greater than 0.5 (see Table 2) and converged on only one construct (Fornell and Larcker 1981). Finally, to test discriminant validity, we checked that each construct shared more variance with its own measures than with the other constructs in the model (Fornell and Larcker 1981); that is, for each construct, the square root of the AVE is greater than correlations among constructs (see Table 2). In addition, we checked that the value one did not appear in the confidence interval of correlations (plus or minus two standard errors around the correlation) between the different variables (see Table 3). All pair of constructs satisfied these criteria.

\subsubsection{Common method variance}

As the data were collected using a single survey, possible common method bias should be evaluated. First of all, it is important to note that this study followed procedural recommendations to minimize this concern through the study design (Podsakoff et al. 2003). For example, the questionnaire: (1) includes a psychological separation between the independent and dependent variables by including other questions not related to the research objective (e.g., socio-demographics, social media use); (2) allows respondents' answers to be anonymous; (3) assures

Table 2 Construct reliability, convergent validity, and discriminant validity

\begin{tabular}{lllllllllll}
\hline Construct & $(1)$ & $(2)$ & (3) & (4) & (5) & (6) & (7) & (8) & CR & AVE \\
\hline Efficiency (1) & $\mathbf{0 . 8 5 1}$ & & & & & & & & 0.955 & 0.725 \\
System availability (2) & 0.799 & $\mathbf{0 . 8 2 3}$ & & & & & & & 0.863 & 0.677 \\
Fulfillment (3) & 0.693 & 0.501 & $\mathbf{0 . 8 2 9}$ & & & & & & 0.939 & 0.688 \\
Privacy (4) & 0.505 & 0.724 & 0.524 & $\mathbf{0 . 8 8 2}$ & & & & & 0.913 & 0.778 \\
Working conditions (5) & 0.396 & 0.373 & 0.443 & 0.604 & $\mathbf{0 . 9 1 2}$ & & & & 0.972 & 0.832 \\
Intention to use (6) & 0.590 & 0.521 & 0.565 & 0.581 & 0.521 & $\mathbf{0 . 9 5 8}$ & & & 0.971 & 0.918 \\
Intention to recommend (7) & 0.667 & 0.556 & 0.668 & 0.608 & 0.627 & 0.873 & $\mathbf{0 . 9 3 9}$ & & 0.957 & 0.881 \\
Price (8) & 0.573 & 0.440 & 0.529 & 0.541 & 0.451 & 0.565 & 0.630 & $\mathbf{0 . 9 3 0}$ & 0.927 & 0.865 \\
\hline
\end{tabular}

Diagonal elements (in bold) are the square root of the AVE (variance shared between the constructs and their measures). Off-diagonal elements are the correlations among constructs 
Table 3 Correlations confidence interval

\begin{tabular}{llllllll}
\hline Pair of constructs & Correlation & \multicolumn{2}{l}{$\begin{array}{l}\text { Confidence } \\
\text { interval } 95 \%\end{array}$} & Pair of constructs & Correlation & $\begin{array}{l}\text { Confidence } \\
\text { interval 95\% }\end{array}$ \\
\hline$(1)-(2)$ & 0.799 & 0.755 & 0.843 & $(3)-(5)$ & 0.443 & 0.365 & 0.521 \\
$(1)-(3)$ & 0.693 & 0.639 & 0.747 & $(3)-(6)$ & 0.565 & 0.497 & 0.633 \\
$(1)-(4)$ & 0.505 & 0.431 & 0.579 & $(3)-(7)$ & 0.668 & 0.612 & 0.724 \\
$(1)-(5)$ & 0.396 & 0.314 & 0.478 & $(3)-(8)$ & 0.529 & 0.457 & 0.601 \\
$(1)-(6)$ & 0.590 & 0.526 & 0.654 & $(4)-(5)$ & 0.604 & 0.54 & 0.668 \\
$(1)-(7)$ & 0.667 & 0.611 & 0.723 & $(4)-(6)$ & 0.581 & 0.515 & 0.647 \\
$(1)-(8)$ & 0.573 & 0.507 & 0.639 & $(4)-(7)$ & 0.608 & 0.544 & 0.672 \\
$(2)-(3)$ & 0.501 & 0.447 & 0.555 & $(4)-(8)$ & 0.541 & 0.471 & 0.611 \\
$(2)-(4)$ & 0.724 & 0.644 & 0.804 & $(5)-(6)$ & 0.521 & 0.451 & 0.591 \\
$(2)-(5)$ & 0.373 & 0.285 & 0.461 & $(5)-(7)$ & 0.627 & 0.567 & 0.687 \\
$(2)-(6)$ & 0.521 & 0.445 & 0.597 & $(5)-(8)$ & 0.451 & 0.375 & 0.527 \\
$(2)-(7)$ & 0.556 & 0.482 & 0.63 & $(6)-(7)$ & 0.873 & 0.847 & 0.899 \\
$(2)-(8)$ & 0.440 & 0.356 & 0.524 & $(6)-(8)$ & 0.565 & 0.499 & 0.631 \\
$(3)-(4)$ & 0.524 & 0.45 & 0.598 & $(7)-(8)$ & 0.630 & 0.57 & 0.69 \\
\hline
\end{tabular}

Efficiency (1), system availability (2), fulfillment (3), privacy (4), working conditions (5), intention to use (6), intention to recommend (7), price (8)

that no right or wrong answers exist, so that respondents should answer questions as honestly as possible; and (4) includes items that were carefully constructed to reduce their ambiguity (Podsakoff et al. 2003; García et al. 2008).

However, when predictor and criterion variables are not obtained from different sources, and are not measured in different contexts, the source of the method bias cannot be identified (Podsakoff et al. 2003). In this situation, following these authors' recommendations, it is also possible to assess common method variance statistically by employing confirmatory factor analyses controlling for the effects of an unmeasured latent methods factor. Specifically, following Bagozzi et al. (1991), we estimated four models including the variables in the present study to assess the amount of trait, method and error variance. Thus, we developed: (1) a null model in which variance in measures is explained only by random error, (2) a trait-only model in which variance in measures is explained by traits plus random error; (3) a method-only model in which variance in measures is explained completely by method factor plus random error; and (4) a trait-method model in which trait factors, method factor and random error are combined to explain the variance in measures. The null model is, therefore, nested in both the methodonly and trait-only models, and the method-only and trait-only models are nested in the trait-method model (Bagozzi et al. 1991). As a result, $\chi^{2}$ differences can be used to test for the presence of trait and method variance. The results in Table 4 show that models 2 and 4 fit significantly better than models 1 and 3, respectively, implying that variance due to traits appears to be present (Bagozzi et al. 1991). Nevertheless, we should acknowledge that some variance is due to the method, as 
Table 4 Summary of nested confirmatory factor analysis tests for trait and method effects

\begin{tabular}{lccclccc}
\hline Model & $\chi^{2}$ & $d f$ & $p$ & Model comparison & $\chi^{2}$ difference & $d f$ & $p$ \\
\hline Null (1) & $20,004.946$ & 630 & $<0.001$ & $(1)-(2)$ & $18,263.962$ & 64 & $<0.001$ \\
Trait-only (2) & 1740.984 & 566 & $<0.001$ & $(3)-(4)$ & 8841.861 & 64 & $<0.001$ \\
Method-only (3) & $10,168.425$ & 594 & $<0.001$ & $(1)-(3)$ & 9836.521 & 36 & $<0.001$ \\
Trait-method (4) & 1326.564 & 530 & $<0.001$ & $(2)-(4)$ & 414.420 & 36 & $<0.001$ \\
\hline
\end{tabular}

models 3 and 4 fit significantly better than models 1 and 2, respectively (Bagozzi et al. 1991). In any case, trait factors are the main source of variance and model fit especially improves when trait variance is considered.

\subsubsection{Multidimensionality of E-S-QUAL}

Previous literature has suggested that e-service quality is formed by different dimensions (e.g., Parasuraman et al. 2005). Specifically, the E-S-QUAL suggests four dimensions: efficiency, system availability, fulfillment and privacy (e.g., Marimon and Cristóbal 2012; Parasuraman et al. 2005). To understand whether these four dimensions form a multidimensional structure, two alternative models were compared following a rival model strategy (Anderson and Gerbing 1988). On the one hand, a first-order model in which the dimensions were not differentiated was developed (all items formed a first-order factor). On the other hand, a second-order model (Steenkamp and Van Trijp 1991) with four dimensions (measuring efficiency, system availability, fulfillment and privacy) was evaluated. Fit indicators shown in Table 5 were much better in the second-order model than in the first-order model, suggesting the multidimensionality of the construct e-service quality.

\subsection{Results}

\subsubsection{Hypotheses test}

To test the proposed hypothesis H1-H5, a structural equation model was developed. Specifically, covariance-based structural equation modeling is employed, using the statistical software EQS 6.1, because it is a confirmatory method that tends to replicate the existing covariation among measures (e.g., Fornell and Bookstein 1982; Hair et al. 2010). Results of the structural equation model are summarized in Fig. 1. The model fit showed acceptable values $\left[\chi^{2}=2253.551,583 d f, p<0.000\right.$;

Table 5 Fit indices for the multidimensionality analysis

\begin{tabular}{lllllll}
\hline Model & $\chi^{2}$ & NNFI & CFI & IFI & RMSEA & 90\% interval RMSEA \\
\hline First-order & $3154.546(188 d f), p<0.01$ & 0.644 & 0.681 & 0.682 & 0.184 & $(0.178 ; 0.190)$ \\
Second-order & $972.599(185 d f), p<0.01$ & 0.904 & 0.915 & 0.916 & 0.096 & $(0.090 ; 0.102)$ \\
\hline
\end{tabular}




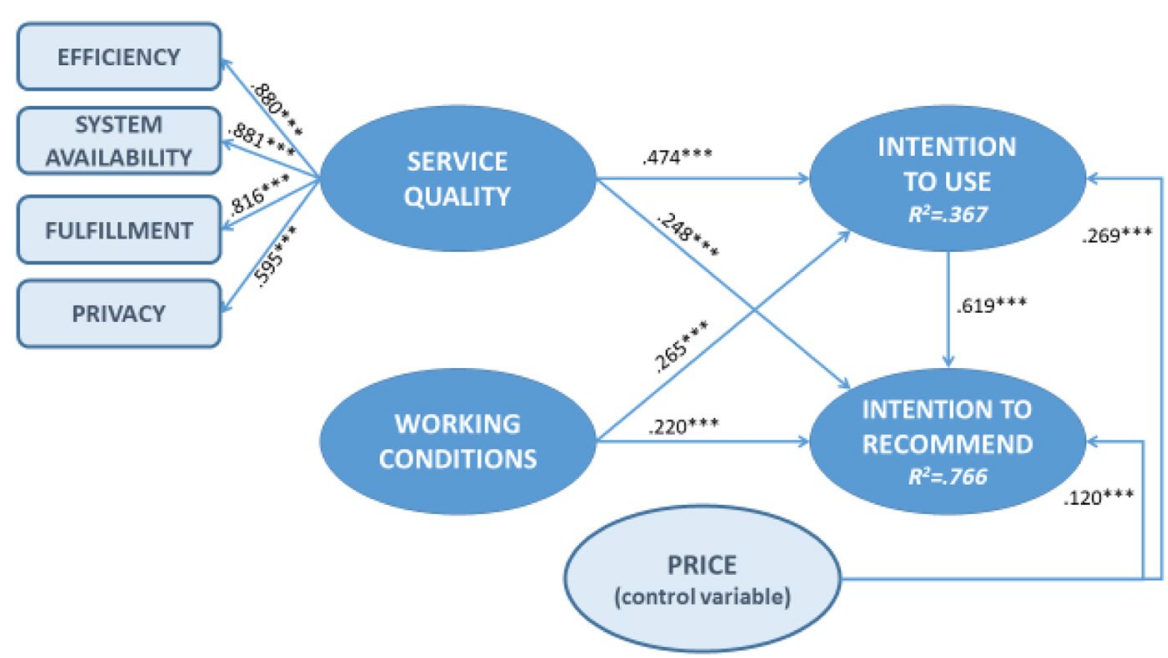

Fig. 1 Results of the research model. Triple asterisks represent coefficients significant at 0.01

$\mathrm{NNFI}=0.907 ; \mathrm{CFI}=0.914 ; \mathrm{IFI}=0.914 ; \mathrm{RMSEA}=0.078 ; 90 \%$ confidence interval $(0.075,0.082)]$.

Our results indicate that service quality has a positive significant effect on intention to use $(\gamma=0.474, p<0.01)$, and intention to recommend the food delivery service $(\gamma=0.248, p<0.01)$, in support of $\mathrm{H} 1$ and $\mathrm{H} 2$. We find support for H3 because customers' perceptions of employees' working conditions significantly influence customers' intention to use the food delivery services $(y=0.265, p<0.01)$. Moreover, consumers who perceive that employees enjoy good working conditions tend to recommend the food delivery services $(\gamma=0.220, p<0.01)$, supporting H4. Finally, in support of $\mathrm{H} 5$, intention to use food delivery service has a positive significant effect on intention to recommend the service $(\beta=0.619, p<0.01)$. In relation to the control variable, we find a positive significant effect of price on both intention to use $(y=0.269, p<0.01)$ and intention to recommend $(y=0.120, p<0.01)$ the food delivery service. These relationships can largely explain our dependent variables: intention to use $\left(R^{2}=0.367\right)$ and intention to recommend $\left(R^{2}=0.766\right)$ the food delivery service.

\subsubsection{Multisample analysis: Spain vs. United States}

Previous studies have suggested that cultural differences may affect the formation of consumer intentions (e.g., Belanche et al. 2015)—an aspect that is crucial in online services that are being spread globally, as is the case for our research context. The sample comprised participants from two countries (i.e., Spain and the U.S.), which involve Latin and Anglo-Saxon countries, as well as American and European ones, in order to evaluate whether the influence of the antecedents of intentions to use and recommend depends on the participant's culture. 
To this end, and following previous studies that have evaluated path differences among samples from different countries (e.g., Sultan et al. 2009; Belanche et al. 2019), a multisample analysis was performed considering two groups: participants from Spain $(N=242)$ and the U.S. $(N=224)$. This analysis facilitates the comparison between parameters. Even though all proposed relationships are positive and significant in both samples, the results of this analysis reveal two interesting differences between countries (see Table 6). Specifically, the influence of e-service quality on intention to use is significantly higher in Spain than in the U.S. $\left[\chi_{\mathrm{d}}^{2}\right.$ $(1)=4.589 ; p<0.05]$. Regarding the relationship between intention to use and intention to recommend, this influence is again significantly higher for Spanish users than for American ones $\left[\chi_{d}^{2}(1)=4.837 ; p<0.05\right]$ In spite of these differences due to participants' nationality, the parameters estimated for each country provide consistent results with the model considering the whole sample.

\section{Socially conscious consumption}

To further advance on Study 1 findings, we propose that the effect of labor conditions on intentions to use and recommend may vary among customers depending on their level of social consciousness in their consumption decisions, a factor considered a customers' trait (Wesley et al. 2012).

Debates about the importance of ethical consumerism (Auger et al. 2008; Edinger-Schons et al. 2018) suggest that contemporary consumer society is interested in responsible consumption, and consumers who identify as "responsible" represent a growing segment (Ulusoy 2016). A key component of social consumerism is the significance of the corporate social values of a company, its products, and its business processes (Devinney et al. 2006), as should be applicable in food services sectors too (Jeng and Yeh 2016). That is, consumers grant increasing consideration to fair business processes, with notable financial implications (Carrigan et al. 2004; Flurry and Swimberghe 2016), prompting growing research and managerial interest in socially conscious consumption (Balderjahn et al. 2013).

Table 6 Multisample analysis: Spain vs. U.S.

\begin{tabular}{|c|c|c|c|c|c|}
\hline \multirow[t]{2}{*}{ Constraints } & \multicolumn{2}{|c|}{ Estimated coefficients } & \multirow[t]{2}{*}{$d f$} & \multirow[t]{2}{*}{$\chi^{2}$ difference } & \multirow[t]{2}{*}{ Probability } \\
\hline & Spain & U.S. & & & \\
\hline E-service quality $\rightarrow$ intention to use & $0.870 * * *$ & $0.470 * * *$ & 1 & 4.589 & 0.032 \\
\hline Working conditions $\rightarrow$ intention to use & $0.252^{* * * *}$ & $0.284 * * *$ & 1 & 0.016 & 0.901 \\
\hline Price $\rightarrow$ intention to use & $0.183 * * *$ & $0.352 * * *$ & 1 & 0.044 & 0.834 \\
\hline E-service quality $\rightarrow$ intention to recommend & $0.259 * * *$ & $0.276 * * *$ & 1 & 2.540 & 0.111 \\
\hline Working conditions $\rightarrow$ intention to recommend & $0.159 * * *$ & $0.234 * * *$ & 1 & 0.021 & 0.884 \\
\hline Price $\rightarrow$ intention to recommend & $0.133 * * *$ & $0.129 * * *$ & 1 & 0.447 & 0.504 \\
\hline Intention to use $\rightarrow$ intention to recommend & $0.627 * * *$ & $0.448 * * *$ & 1 & 4.837 & 0.028 \\
\hline
\end{tabular}

$* * *$ Coefficients significant at 0.01 
Socially conscious consumption involves consumer buying behavior that accounts for ethical issues, such as human rights, labor conditions, or environmental implications (Wesley et al. 2012). Socially conscious consumers worry about how their consumption behaviors affect others and the world, and they seek positive social changes (Roberts 1993), such as by supporting socially responsible businesses that exhibit their consideration of social issues too (Ulusoy 2016; Webb et al. 2008) and boycotting firms that engage in irresponsible practices (Shobeiri et al. 2016). These consumers believe socially conscious behaviors benefit all of society, not just them personally (Wesley et al. 2012). For example, they might seek fair trade products and services (de Pelsmacker and Janssens 2007; Gosselt et al. 2017; Kim et al. 2010), which guarantee equitable treatment of all stakeholders involved in a commercial exchange (Moore 2004). Their purchases of fair trade products thus may be driven by prosocial motives but also by self-restoration needs (Trudel et al. 2020) and a desire to feel good about themselves. Overall, socially conscious consumers should be more likely to exert effort to purchase of fair trade offerings (Kang et al. 2013). Despite some debate about what defines a fair trade firm (Connolly and Shaw 2006), a consistent consideration is protection of workers' rights (Rashid and Byun 2018). Therefore, we propose that:

H6 Improving working conditions for food delivery workers has a greater impact on intention to use the service among socially conscious customers.

H7 Improving working conditions for food delivery workers has a greater impact on intention to recommend the service among socially conscious customers.

\section{Study 2}

\subsection{Design and procedure}

This scenario-based experiment tests again whether improved working conditions might increase customers' intentions to use and recommend the food delivery service $(\mathrm{H} 3-\mathrm{H} 4)$, as well as the potential moderating effect of socially conscious consumption (H6-H7). The participants are 128 U.S. customers of food delivery services, recruited by the same process than in Study 1 . Of all respondents, $50.8 \%$ were women and $49.2 \%$ men; $10.2 \%$ were aged between 18 and 24 years, $25.8 \%$ between 25 and 34 years, $25.0 \%$ between 35 and 44 years, $21.9 \%$ between 45 and 54 years, and $17.2 \%$ were older than 54 years; and $38.3 \%$ had completed secondary studies, 49.2\% had some university education, and $12.5 \%$ had advanced degrees. Again, sample demographics are also similar to those of U.S. customers of food delivery services. In terms of service experience, $37.6 \%$ used food delivery services at least once a year, $35.1 \%$ once a moth, $23.4 \%$ once a week, and $3.9 \%$ more than once a week. The study followed a two (improved vs. maintained working conditions) $\times$ two (high vs. low social conscious consumers) between-subjects experimental design. Participants' levels of social conscious consumption were measured through a scale, whereas companies' improvement (or continuance) of the working conditions of 
their deliverers were manipulated by the use of scenarios. Using a method proposed by Bagozzi et al. (2016), we manipulated the improvement in working conditions by adapting a newspaper article about a food delivery company. Thus, participants were randomly assigned to one of the two following scenarios:

In the improved working condition scenario, participants read:

Considering deliverers' demands about their working conditions and the legal controversy about their situation, the firm is going to improve the labor conditions of their deliverers. From now on, the company will cover accident insurance for each worker; deliverers will have an agreed working schedule, they will be well rewarded if taking extra orders, and would not be punished for refusing orders.

In the maintained working condition scenario, they instead read:

Despite deliverers' demands about their working conditions and the legal controversy about their situation, the firm is going to maintain the same labor conditions of their deliverers. The company would not cover accident insurance, which should be assumed by each deliverer. Depending on the firm needs, deliverers could be requested at any day of the week and could be punished for refusing orders in high-demand hours.

After that, participants completed the items to measure the key variables and provided basic demographic information. Finally, participants were thanked and debriefed.

\subsection{Measures}

The measures for working conditions, intention to use, and intention to recommend were the same as we used in Sect. 1. For socially conscious consumption, we rely on four items on a 7-point scale (Pepper et al. 2011), as presented in the Appendix. The questionnaire was administered exclusively in English.

The dimensional structure of the scales was performed by the same procedure used in Study 1. Again, two items (WOR8, as in the previous study, and SOCC1) needed to be eliminated after checking the factor loadings of the confirmatory model. To test convergent validity, we confirmed that CR indicators were above 0.65 (Steenkamp and Geyskens, 2006) and AVE values were greater than 0.5, as presented in Table 7 . We also checked discriminant validity by confirming that the square root of the AVE was greater than the correlations among constructs (see Table 7).

\subsection{Results}

As a manipulation check, we confirmed that the average values on the working condition scale were higher among respondents randomly assigned to the improved working conditions scenario than among those in the maintained working conditions scenario $\left(M_{\text {Improved }}=5.08, M_{\text {Maintained }}=2.57, t=11.90, p<0.01\right)$. 
Table 7 Construct reliability, convergent validity, and discriminant validity

\begin{tabular}{lllllll}
\hline & $(1)$ & $(2)$ & $(3)$ & (4) & CR & AVE \\
\hline Working conditions (1) & $\mathbf{0 . 9 0 5}$ & & & & 0.969 & 0.820 \\
Socially conscious consumption (2) & 0.173 & $\mathbf{0 . 8 1 6}$ & & & 0.854 & 0.665 \\
Intention to use (3) & 0.817 & 0.128 & $\mathbf{0 . 9 8 6}$ & & 0.991 & 0.973 \\
Intention to recommend (4) & 0.884 & 0.154 & 0.896 & $\mathbf{0 . 9 7 7}$ & 0.984 & 0.954 \\
\hline
\end{tabular}

Diagonal elements (in bold) are the square root of the AVE (variance shared between the constructs and their measures). Off-diagonal elements are the correlations among constructs

The linear regression analysis with intention to use the service as the dependent variable also includes interaction terms, for which we mean-centered the constructs to avoid multicollinearity (Jaccard and Wan 1996). Consumers who perceive improved working conditions reveal the positive direct impact of this assessment on their intention to use the service $(\beta=0.62, p<0.01)$, in support of H3. The direct effect of socially conscious consumption on intention to use also is significant but negative $(\beta=-0.32, p<0.01)$; socially conscious customers tend to avoid the use of these services. In support of the moderating effect proposed in H6, the interaction term of working conditions and socially conscious consumption exerts a significant impact on intention to use $(\beta=0.41, p<0.01)$.

The results related to intention to recommend the food delivery service reveal a similar pattern. Improved working conditions significantly increase customers' intention to recommend the service $(\beta=0.73, p<0.01)$, in support of H4. Higher levels of socially conscious consumption reduce the intention to recommend $(\beta=-0.27, p<0.01)$, and its interaction with improved working conditions exerts a significant influence on this intention too $(\beta=0.36, p<0.01)$, in support of the moderating effect proposed in $\mathrm{H} 7$.

For deeper insights, we also tested the direct and interaction effects with a $2 \times 2$ analysis of variance (ANOVA). Following standard procedures, we assigned participants to the high or low socially conscious group according to a split at the average of the socially conscious consumption scores, plus or minus one-half the standard deviation (Jaccard and Wan 1996). The ANOVA results confirm H3: Perceptions of improved working conditions increase the intention to use the service $(F=33.11$, $p<0.01)$. However, the level of socially conscious consumption does not affect this intention $(F=0.90, p>0.10)$. In support of the moderating effect in H6 $(F=8.32$, $p<0.01$, improved working conditions strongly stimulate intention to use the service among highly socially conscious customers, for whom maintained working conditions also are particularly undesirable. Improving working conditions is relatively less effective among less socially conscious customers, whose intention to use is less affected by working conditions. Figure 2 illustrates the moderating effect.

Similarly, the ANOVA results confirm H4, in that improved working conditions exert direct, positive impacts on customers' intention to recommend the food delivery service $(F=62.29, p<0.01)$. Levels of socially conscious consumption do not influence this intention $(F=0.33, p>0.10)$, but they interact with the effectiveness of improved working conditions $(F=9.07, p<0.01)$, as we predicted in H7. In 


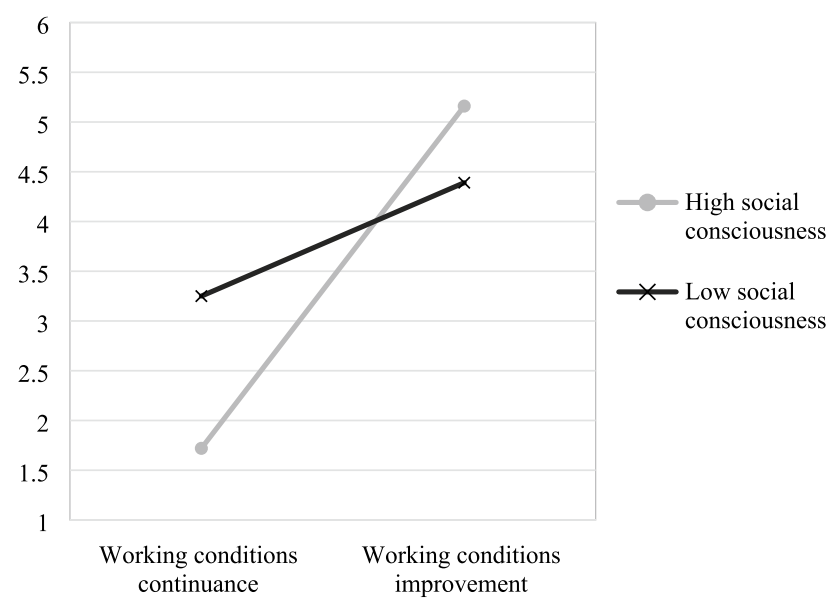

Fig. 2 Interaction between working conditions and socially conscious consumption: intention to use

Fig. 3, customers' intention to recommend the service are particularly relevant for highly socially conscious consumers, for whom maintained working conditions also are detrimental. Among less socially conscious consumers, the influence of a change in the working conditions of delivery workers is less relevant for their recommendation intention.

To establish some segmentation insights for marketers, we also sought to profile socially conscious consumers in terms of their age, gender, and level of education. The results of a regression analysis with socially consciousness consumption as the dependent variable reveal that consciousness levels depend strongly on gender $(\beta=0.28, p<0.05)$, in that woman are more socially conscious than men,

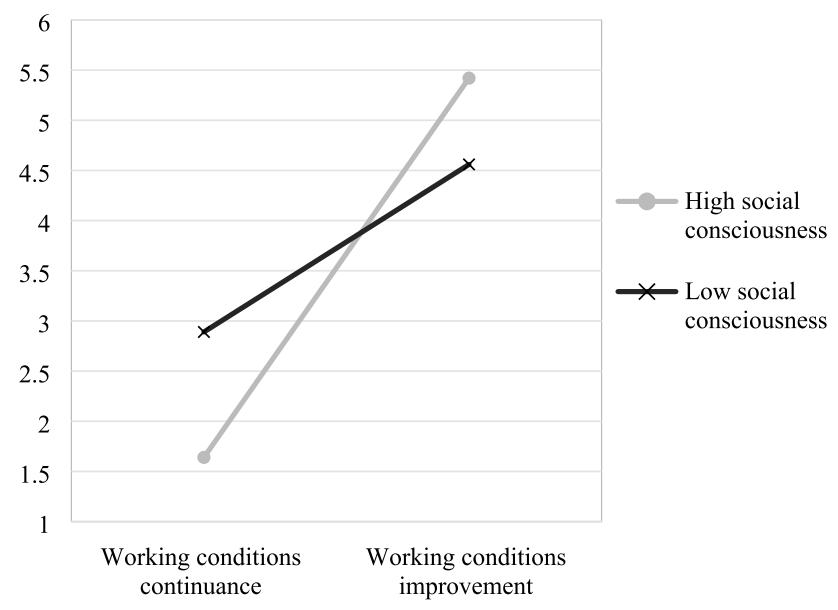

Fig. 3 Interaction between working conditions and socially conscious consumption: intention to recommend 
and marginally on the level of education $(\beta=0.16, p<0.10)$, that is customers with higher education are slightly more socially conscious. They are not influenced by customers' ages $(\beta=0.05, p>0.10)$.

\section{Study 3}

\subsection{Design and procedure}

With this third study, we assess experimentally whether customers will devote extra effort to patronize a food delivery company that offers better working conditions than its competitors. Improving working conditions likely has some cost for the company, which might push some of that cost down to customers, as a trade-off for being served by delivery drivers who enjoy better working conditions. Therefore, we manipulate the amount of costs customers bear, in terms of delivery time (longer wait) and price (premium price), which reflect common service costs assumed by customers, depending on the firm's operations management (Bortolini et al. 2016; He et al. 2019). With this experimental design, we again seek to establish useful advice for practitioners regarding which operational changes they should implement, depending on the limits of what customers are willing to bear in terms of time and monetary costs.

The participants were another group of 128 U.S. customers, recruited using the same methods as in Study 1. The sample includes 51.6\% women and $49.4 \%$ men; $23.4 \%$ were aged between 25 and 34 years, $74.2 \%$ between 35 and 44 years, and $2.3 \%$ between 45 and 54 years; and $35.9 \%$ had a secondary education, $44.5 \%$ a university education, and $19.5 \%$ an advanced degree. Sample demographics are similar to those of U.S. customers, though mid-age customers were overrepresented in the sample. They had some experience with food delivery services, $35.9 \%$ used them at least once a year, $40.7 \%$ once a moth, $20.3 \%$ once a week, and $3.1 \%$ more than once a week. After introducing the study as an academic research about food delivery services, we randomly assigned the participants to one of three delivery time scenarios, as well as one of three price scenarios. A pretest with a different sample of 102 participants helped us determine the average delivery time and cost of orders, as reported by regular U.S. customers of food delivery services, as well as confirm the understanding of the provided scenarios. The pretest results indicate that companies need an average of $38.38 \mathrm{~min}(S D=14.91)$ to deliver food to homes after the order is placed, and customers spend US\$27.74 $(S D=12.11)$ on average per order. These values provide the baseline time and price for Study 3. Then, all the scenarios started with the following description:

Imagine than one day you are with your friends at home and decide to ask for some food for dinner. When choosing about which food delivery service to use you have the following options:

In the delivery time manipulations, the alternatives to the regular service cited a food delivery service that offers better working conditions but a 10 , 30, or $50 \%$ longer delivery time: 
Company A offers a regular service and delivers your order to your home in 38 min. Company B has improved the working conditions of their deliverers, covering accident insurance, agreed working schedule, better rewards for accepting orders and lack of punishment for refusing orders. Company B delivers your order to your home in $42 \mathrm{~min}[50,57]$ minutes.

For the price manipulation, the alternative service with better working conditions cost U.S. \$30.50, U.S. \$33.30, or U.S. \$36.10, representing 10, 20, or 30\% premiums over the average price of U.S. \$27.74. In each scenario, participants had to choose which option (A or B) they prefer. Some demographic information was collected at the end of the study.

\subsection{Results}

The results reveal that customers would be willing to accept some costs to improve delivery drivers' working conditions. In particular, $82.5 \%$ of customers would be willing to wait $10 \%$ longer, and $61.0 \%$ would not mind waiting $30 \%$ longer to be served by a food delivery company that offers better working conditions. Figure 4 depicts customers' preference for each option, showing that these preferences varies significantly depending on delivery times that are 10\%, 30\%, and 50\% higher than the regular delivery time offered by a service that has not improved working conditions (Pearson $\chi^{2}=10.65, p<0.01$ ).

For the price analysis, we find that $55.3 \%$ of participants would prefer to be served by a food delivery company with improved working conditions even if they have to pay a $10 \%$ premium. However, with a 20 or $30 \%$ price increase, most respondents prefer to be served by the regular company with maintained working conditions. Again, preferences significantly varies depending on the price increase (Pearson $\chi^{2}=8.01, p<0.05$ ), as Fig. 5 shows.

In summary, the Study 3 results provide further support for H3: Customers prefer a company that offers improved working conditions, even if they must renounce

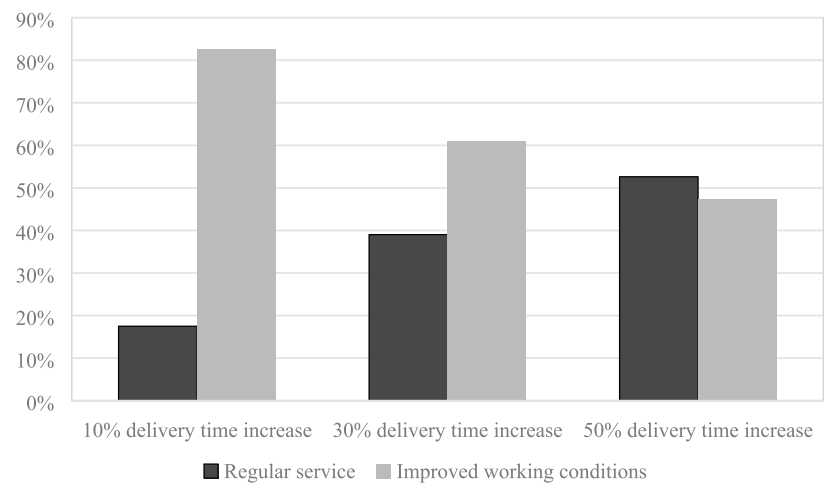

Fig. 4 Customer preferences (percentage) for service provided by a company with improved working conditions, depending on delivery time 


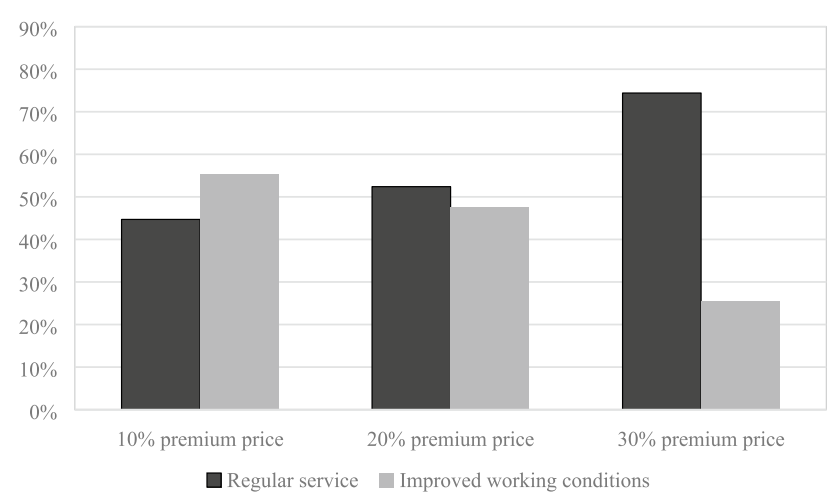

Fig. 5 Customer preferences (percentage) for service provided by a company with improved working conditions, depending on price premium

some service benefits to buy from it. In particular, most customers would not mind waiting longer (up to $30 \%$ ) to be served by delivery drivers with better working conditions. However, they are less willing to pay a premium to be served by such companies; the majority of them reject paying a $20 \%$ or $30 \%$ premium price, and only $55.3 \%$ would be willing to pay a $10 \%$ premium to receive deliveries from drivers who enjoy improved working conditions.

\section{Discussion}

Workers in the growing gig economy sell their labor through online apps (Taylor et al. 2017), yet the related labor practices have emerged as highly controversial, due to the presence of information asymmetry, real-time controls, and unsafe conditions (Veen et al. 2019). To address this expanding global business model and its implications, we explore how customers perceive the working conditions of workers in the gig economy, in the specific context of food delivery services. With three studies, we expand extant knowledge with a marketing perspective and provide empirical evidence that in turn suggests practical guidance for managing such platforms more effectively.

By applying the E-S-QUAL framework (Parasuraman et al. 2005), we establish in Study 1 that service quality exerts strong positive impacts on customers' intentions to use and recommend. Our results support that providing customers with an efficient and technically available service platform that ensures customers privacy and their fulfillment of the promises is relevant to guarantee service provision quality through food delivery platforms. These findings agree with those obtained in studies applying E-S-QUAL framework in other digital contexts (Belanche et al. 2014; Eisingerich et al. 2015) and complement recent research that disregard service quality and the E-S-QUAL dimensions when investigating the factors motivating the use of food delivery services (Cho et al. 2019; Lee et al. 2019; Ray et al. 2019). The direct influences of price (as a control variable) 
and intention to use on recommendation intention also aligns with theoretical predictions about consumers' desire to see themselves in a positive light, using beneficial outcomes that they present favorably to peers (Eisingerich et al. 2015; Gregg et al. 2011).

Beyond these service quality insights, our study contributes to the growing evidence that customers are concerned about social issues and how they affect others or the overall community. In particular, our research reveals that customers are not only aware about the unfair labor conditions of the workers of food delivery services, but they internalize such concerns in a high extent, with these perceptions resulting in a higher (lower) preference for food delivery platforms depending on their labor practices. More precisely, Study 1 explores customers' perceptions of working conditions and finds that this factor influences significantly both intentions to use and recommend a food delivery service. Thus, customers themselves go beyond classical service quality dimensions when deciding whether to use and recommend food delivery services, reflecting the influences of their perceptions of firms' social responsibility (Jeng and Yeh 2016). In other words, customers deciding whether to use and recommend food delivery platforms are not only motivated by practical and hedonic reasons as suggested in previous research (Ray et al. 2019; Yeo et al. 2017), but they also take into account the integral relationship that these companies develop with their workers. In this regard, our results suggest that customers decide if they support or not the kind of labor practices carried out by some platforms of the gig economy using and recommending their services.

To further support this insight, the results of Study 2 reveals that customers will be more willing to use and recommend food delivery services when these companies are committed to improving the working conditions of their employees, compared to companies that maintain current labor practices of the gig economy. This finding confirms that customers play a crucial role in supporting companies implementing fairer labor practices in the management of delivery workers or punishing platforms imposing controversial or unfair working conditions to their deliverers. In this vein, our research suggests that consumer may be empowered to impel companies of the gig economy to improve their working conditions according to their demands. This consumer empowerment, a concept frequently used in other online contexts (e.g., social media, ad blocking, Belanche et al. 2020a), could be manifested through two key consumption decisions: platform selection and recommendation to other customers.

Nevertheless, our research also finds that not all the customers of food delivery services take the service workers' labor conditions into account in determining their behavioral intentions. In particular, customers with lower levels of social consciousness are less concerned, but highly socially conscious consumers are strongly influenced by working condition considerations. Therefore, socially conscious consumption should be included as a relevant customer trait that influences their actions in the context of the gig economy, as well as analyzed in light of the expanded public concern about community welfare and the link between local issues and global challenges. Notably, as people protest global initiatives that threaten their local labor markets (e.g., robotics, globalization; Fulgoni 2018; Granulo et al. 2019), companies' dedicated efforts to ensure good working conditions for gig economy workers 
might help persuade socially conscious consumers about the potential benefits of the new initiatives.

From a more practical approach, assuming that improved working conditions likely increase firm costs, we also investigate whether customers might be willing to assume some of the costs, in the form of increased delivery times and prices (Bortolini et al. 2016; He et al. 2019). As we specify in our last study, most customers are willing to wait longer to receive a delivery from a driver working under good conditions, but they are only willing to pay a $10 \%$ premium. Thus, in general, customers appear to prefer to assume a time cost rather than a monetary cost, probably because price continues being crucial for service provider selections in e-commerce and food delivery contexts (Audrain-Pontevia et al. 2013; Cho et al. 2019). Yet customers of food delivery platforms appear willing to renounce one of the principal benefits of using these services, namely, time savings (Yeo et al. 2017). Perhaps customers link platforms that provide better working conditions with traditional food delivery services, such as restaurants, so they can understand why they need to give up some convenience to limit the labor pressures on workers. Thus, our findings reveal that customers would accept some sacrifices as a trade-off, suggesting that the improvement of the labor practices generates a greater value that compensates the reduction in other quality factors (i.e., quick service). By choosing companies with better working conditions, customers' will agree with the reduction of some of the advantages of these services in order to contribute to the community well-being.

\subsection{Managerial implications}

Our implementation of the E-S-QUAL model suggests some guidelines that managers can follow to pursue business success in the food delivery service market. Service quality continue being a key factor determining customers' intentions to use and recommend the service also in the new online initiatives implemented in the food delivery sector. In particular, companies should emphasize efficiency, system availability, fulfillment, and privacy provisions. Firms should devote particular attention to designing user-friendly online platforms and make them available 24/7; providing users with information during the entire delivery process and ensuring ontime and accurate deliveries; and protecting their credit card data or using security certifications to ensure no breaches of financial information.

In addition, food delivery service providers should ensure good working conditions for workers if they want to convince consumers to buy from and recommend them. Ethical consumerism continues to gain in importance worldwide (Edinger-Schons et al. 2018), so companies must continue to expand their socially responsible and fair labor practices. Arguably, food delivery service firms might want to shift away from the gig economy or adapt the new business model to include socially responsible and sustainable considerations (Plewnia and Guenther 2018). In particular, firms might offer better incentives for self-employed workers, contract with them as company employees, increase their remuneration, provide insurance, or offer some basic income stability guarantees. Thus, improving the labor practices may become a strategical decision to position the brand as a company committed with its corporate social responsibility; 
taking the most from the advantages of the gig economy in the XXIth century (e.g., easy to use on demand platform), but avoiding the use of such technological instruments to limit the rights of vulnerable workers. Once they had done so, and considering that not every platform may follow this strategy, the service firms should communicate these enhanced labor conditions to customers in order to spread such positioning. Indeed, this kind of information about the company social features may become a key determinant of business success (Carrigan et al. 2004; Flurry and Swimberghe 2016). Consequently, companies should carefully manage their marketing messages; they may not focus exclusively on the service convenience and hedonic benefits of online food delivery, but on the fair relationship that the company established with the workers and therefore with the whole community.

Such insights are relevant to firms that deliver food but also to other businesses that have embraced the gig economy. Labor conditions are a substantial concern associated with this business model, such that customers are becoming to express skepticism over firms that fail to provide sufficient protections for their workers. In this vein, our research found socially conscious consumption as a relevant segmentation variable, since improving the labor conditions of their workers would particularly increase sales and recommendations among this group of customers. Indeed, high social conscious customers have lower purchase and recommendation intentions toward food delivery services, but these intentions turn higher than those from low social conscious customers when they have the choice to use a platform with better labor practices. Companies can effectively pursue this segment of the population as potential customers that can be attracted by food delivery services. To do so, companies should first identify social conscious customers. Our research finds that this trait is more frequent among women and more educated people; however, alternative market research actions should be developed to identify this people (e.g., surveys, cross-selling actions linked to other social conscious consumption choices such as fair trade products). When targeting social conscious customers, companies should clearly communicate that they are improving the labor conditions of their workers as a distinctive and central feature of their offerings. In particular, we recommend that companies take the opportunity to be among the first ones to improve working conditions, so they can enjoy pioneering advantages relative to firms that continue to maintain the same poor labor practices.

Finally, our finding that customers are willing to wait for slower deliveries (up to $30 \%$ longer than the average delivery time) as a trade-off for being served by a company that offers improved working conditions suggests that managers should consider rearranging their service operations. They can trade-off better working conditions against other benefits offered by the service delivery, though they likely cannot raise the price. To establish a good quality-price ratio, managers need to respect the price sensitivity of online food delivery service customers.

\subsection{Limitations}

In addition to these contributions, we note some limitations of our studies that could be addressed in continued research. To advance in this underexplored field, we conducted exploratory research with three studies. More detailed 
investigations of users' profiles might reveal other demographic, personal, and situational factors that influence the use and recommendation of services. Our study analyzes North American and Spanish customers of these services; however, to generalize our findings the research should be replicated in other cultural context (e.g., Asian countries).

We assume that improving working conditions implies cost increases, but in some cases, that assumption may not hold, and customers might not be required to assume part of the cost. Alternative sources to create value for customers of food delivery platforms should be explored. In addition to the unfair working conditions, alternative factors (e.g., environmental concerns derived from over-packaging) may demotivate customers to use and recommend food delivery services. Further research should analyze customers' reactions to labor conditions using different measures because consumer empowerment may be manifested by many actions (e.g., reaction to workers' strikes, boycotts). Longitudinal research that considers the evolution of food delivery online platforms might help academics and researchers determine how changes, such as in labor conditions, influence the platforms' use and achieved recommendations over time. In this regard, a field study in collaboration with such platforms could better assess the economic and societal impact derived from the improvement of their working conditions.

\section{Appendix}

Scales items

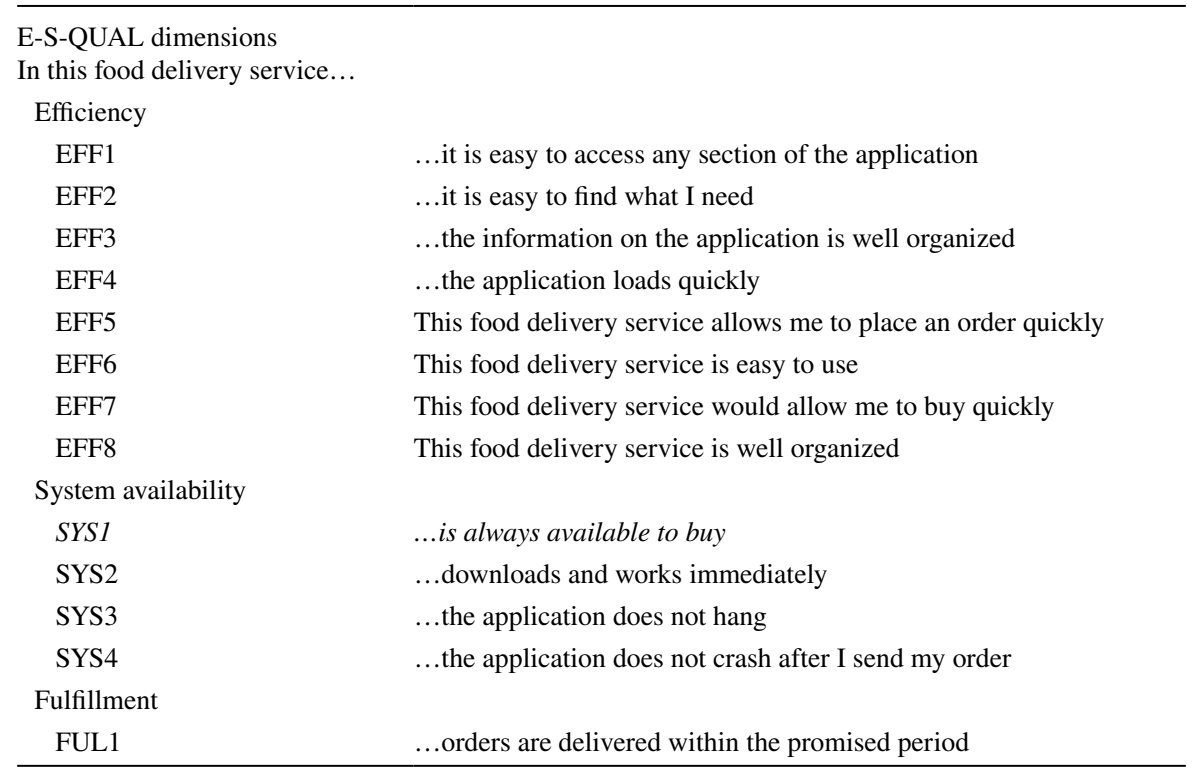




\begin{tabular}{cl}
\hline FUL2 & $\begin{array}{l}\text {..the company makes the order available for delivery within a suit- } \\
\text { able time frame }\end{array}$ \\
FUL3 & $\ldots$ the company quickly delivers what I ask \\
FUL4 & $\ldots$ the company has in stock the articles that the application offers \\
FUL5 & $\ldots$ the company complies with its offers \\
FUL6 & $\ldots$ there are no errors in the order \\
FUL7 & $\ldots$ the company fulfills the promise about the delivery of the products \\
Privacy & $\ldots$ the company protects the information of my purchase behavior \\
PRIV1 & $\ldots$ the company does not share my personal information with other \\
PRIV2 & applications \\
PRIV3 & $\ldots$ the company protects your credit card information \\
PRIV4 & $\ldots$ please answer to this sentence selecting the number two, partici- \\
& pants answering other option will not be rewarded
\end{tabular}

Working conditions

The company...

WOR1

WOR2

WOR3

WOR4

WOR5

WOR6

WOR7

WOR8

Intention to use

When I need it...

IUSE1

IUSE2

IUSE3

Intention to recommend

IREC1

IREC2

IREC3

...respects the rights of employees

...establishes safe and non-hazardous working conditions for the health of its workers

...establishes decent working conditions

...treats employees fairly

...offers adequate remuneration

...develops, supports and trains its employees

...communicates openly and honestly with its employees

...provides a flexible work schedule for employees

...I intend to use this service

...I think I will use this service again

...I would like to use this service again

If someone asked me about this service, I would give a positive opinion

If I had the opportunity, I would highlight the advantages of this service

Price

PRI1

I would recommend this service

PRI2

The service has a reasonable price

The service offers a good quality-price ratio

Socially conscious consumption

SOCC1

$\mathrm{SOCC} 2$

SOCC3
I consider the ethical reputation of businesses when shopping

I deliberately avoid buying products on the basis of a company's unethical behavior

I deliberately use services from companies who provide fair working conditions 
SOCC4 I often buy products with a fair trade label rather than without one

Items in italics were removed from the final questionnaire after the scale validation process.

Acknowledgements This work was supported by the European Social Fund and the Government of Aragon (LMP65_18 and research group "METODO” S20_17R).

\section{References}

Anderson J, Gerbing D (1988) Structural equation modeling in practice: a review and recommended twostep approach. Psychol Bull 103(3):411-423

Audrain-Pontevia AF, N'Goala G, Poncin I (2013) A good deal online: the impacts of acquisition and transaction value on e-satisfaction and e-loyalty. J Retail Consum Serv 20(5):445-452

Auger P, Devinney TM, Louviere JJ, Burke PF (2008) Do social product features have value to consumers? Int J Res Mark 25(3):183-191

Azar OH (2005) The social norm of tipping: does it improve social welfare? J Econ 85(2):141-173

Bagozzi RP, Belanche D, Casaló LV, Flavián C (2016) The role of anticipated emotions in purchase intentions. Psychol Mark 33(8):629-645

Bagozzi RP, Yi Y, Phillips LW (1991) Assessing construct validity in organizational research. Adm Sci Q 36(3):421-458

Balderjahn I, Peyer M, Paulssen M (2013) Consciousness for fair consumption: conceptualization, scale development and empirical validation. Int J Consum Stud 37(5):546-555

Barnes SJ, Vidgen RT (2002) An integrative approach to the assessment of e-commerce quality. J Electron Commerce Res 3(3):114-127

BBC (2019) The dangerous life of food delivery drivers. Agencia EFE, Madrid

Belanche D, Casaló LV, Flavián C (2011) Adopción de servicios públicos online: un análisis a través de la integración de los modelos TAM y TPB. Euro J Manage Bus Econ 20(4):41-56

Belanche D, Casaló LV, Flavián C, Schepers J (2014) Trust transfer in the continued usage of public e-services. Inf Manage 51(6):627-640

Belanche D, Casaló LV, Guinalíu M (2015) The effect of culture in forming e-loyalty intentions: a crosscultural analysis between Argentina and Spain. BRQ-Bus Res Q 18(4):275-292

Belanche D, Casaló LV, Flavián C (2010) Providing online public services successfully: the role of confirmation of citizens' expectations. Int Rev Public Nonprofit Mark 7(2):167-184

Belanche D, Casaló LV, Flavián C, Guinalíu M (2019) Reciprocity and commitment in online travel communities. Ind Manag Data Syst 119(2):397-411

Belanche D, Flavián C, Pérez-Rueda A (2020a) Consumer empowerment in interactive advertising and eWOM consequences: the PITRE model. J Market Comm 26(1):1-20

Belanche D, Flavián M, Pérez-Rueda A (2020b) Mobile apps use and WOM in the food delivery sector: the role of planned behavior, perceived security and customer lifestyle compatibility. Sustainability 12(10):4275

Blut M, Chowdhry N, Mittal V, Brock C (2015) E-service quality: a meta-analytic review. J Retail 91(4):679-700

Bortolini M, Faccio M, Ferrari E, Gamberi M, Pilati F (2016) Fresh food sustainable distribution: cost, delivery time and carbon footprint three-objective optimization. J Food Eng 174:56-67

Brown TJ, Barry TE, Dacin PA, Gunst RF (2005) Spreading the word: investigating antecedents of consumers' positive word-of-mouth intentions and behaviors in a retailing context. J Acad Mark Sci 33(2):123-138

Burtch G, Carnahan S, Greenwood BN (2018) Can you gig it? An empirical examination of the gig economy and entrepreneurial activity. Manage Sci 64(12):5497-5520

Carman T (2019) D.C. sues DoorDash for allegedly pocketing millions in food-delivery workers' tips. Washington Post. https://www.washingtonpost.com/lifestyle/food/dc-sues-doordash-for-allegedlypocketing-millions-in-food-delivery-workers-tips/2019/11/19/5240d7e4-0ae2-11ea-8397-a955c d542d00_story.html. Accessed 12 Feb 2020 
Carrigan M, Szmigin I, Wright J (2004) Shopping for a better world? An interpretive study of the potential for ethical consumption within the older market. J Consum Mark 21(6):401-417

Chen MC, Hsu CL, Hsu CM, Lee YY (2014) Ensuring the quality of e-shopping specialty foods through efficient logistics service. Trends Food Sci Technol 35(1):69-82

Chiang KP, Dholakia RR (2003) Factors driving consumer intention to shop online: an empirical investigation. J Consum Psychol 13(1):177-183

Cho M, Bonn MA, Li JJ (2019) Differences in perceptions about food delivery apps between singleperson and multi-person households. Int J Hosp Manag 77:108-116

Collier JE, Bienstock CC (2006) Measuring service quality in e-retailing. J Serv Res 8(3):260-275

Connolly J, Shaw D (2006) Identifying fair trade in consumption choice. J Strateg Mark 14(4):353-368

De Pelsmacker P, Janssens W (2007) A model for fair trade buying behaviour: the role of perceived quantity and quality of information and of product-specific attitudes. J Bus Ethics 75(4):361-380

De Stefano V (2016) The rise of the 'just-in-time workforce': on-demand work, crowdwork, and labor protection in the 'gig-economy.' Comp Labor Law Policy J 37:471-504

Devinney TM, Auger P, Eckhardt G, Birtchnell T (2006) The other CSR. Stanford Soc Innov Rev 4(3):30-37

Drahokoupil J, Piasna A (2019) Work in the platform economy: deliveroo riders in Belgium and the SMart arrangement. ETUI Research Paper. https://ssrn.com/abstract=3316133. Accessed 18 Jan 2020

Edinger-Schons LM, Sipilä J, Sen S, Mende G, Wieseke J (2018) Are two reasons better than one? The role of appeal type in consumer responses to sustainable products. J Consum Psychol 28(4):644-664

EFE (2020) El Tribunal Supremo reconoce la relación laboral entre Glovo y un repartidor. Agencia EFE, Madrid. https:/www.efe.com/efe/espana/economia/eltribunal-supremo-reconoce-la-relacion-labor al-entre-glovo-y-un-repartidor/10003-4349949. Accessed 12 Oct 2020

Eisingerich AB, Chun HH, Liu Y, Jia HM, Bell SJ (2015) Why recommend a brand face-to-face but not on Facebook? How word-of-mouth on online social sites differs from traditional word-of-mouth. J Consum Psychol 25(1):120-128

Faqih KM (2016) An empirical analysis of factors predicting the behavioral intention to adopt internet shopping technology among non-shoppers in a developing country context: does gender matter? J Retail Consum Serv 30:140-164

Fernández M (2017) Repartidores: un pólemico modelo laboral. El País. https://elpais.com/econo mia/2017/12/01/actualidad/1512151278_358481.html. Accessed 20 Dec 2019

Flurry LA, Swimberghe K (2016) Consumer ethics of adolescents. J Mark Theory Pract 24(1):91-108

Fornell C, Larcker D (1981) Structural equation models with unobserved variables and measurement error. J Mark Res 18(3):382-388

Fornell C, Bookstein FL (1982) Two structural equation models: LISREL and PLS applied to consumer exit-voice theory. J Mark Res 19(4):440-452

Fulgoni GM (2018) Will digital commerce and analytics be the death of traditional brands? J Advert Res 58(2):146-150

García N, Sanzo MJ, Trespalacios JA (2008) Can a good organizational climate compensate for a lack of top management commitment to new product development? J Bus Res 61(2):118-131

Garijo M, Requena A (2016) Así son las condiciones laborales de quienes te reparten la comida a domicilio. El Diario. https://www.eldiario.es/economia/condiciones-reparten-comida-casa_0_58759 1876.html. Accessed 20 Dec 2019

Goods C, Veen A, Barratt T (2019) Is your gig any good? Analysing job quality in the Australian platform-based food-delivery sector. J Ind Rel 61(4):502-527

Gosselt JF, van Rompay T, Haske L (2017) Won't get fooled again: the effects of internal and external CSR ECO-labeling. J Bus Ethics 155(2):413-424

Granulo A, Fuchs C, Puntoni S (2019) Psychological reactions to human versus robotic job replacement. Nat Hum Behav 3(10):1062-1069

Gregg AP, Hepper EG, Sedikides C (2011) Quantifying self-motives: functional links between dispositional desires. Eur J Soc Psychol 41:840-852

Hair J, Black W, Babin B, Anderson R (2010) Multivariate data analysis, 7th edn. Prentice Hall, New Jersey

Hallowell R (1996) The relationships of customer satisfaction, customer loyalty, and profitability: an empirical study. Int J Serv Ind Manag 7(4):27-42 
Harrison-Walker LJ (2001) The measurement of word-of-mouth communication and an investigation of service quality and customer commitment as potential antecedents. J Serv Res 4(1):60-75

Hausman AV (2003) Professional service relationships: a multi-context study of factors impacting satisfaction, re-patronization, and recommendations. J Serv Mark 17(3):226-242

He Z, Han G, Cheng TCE, Fan B, Dong J (2019) Evolutionary food quality and location strategies for restaurants in competitive online-to-offline food ordering and delivery markets: an agent-based approach. Int J Prod Econ 215:61-72

Healy J, Nicholson D, Pekarek A (2017) Should we take the gig economy seriously? Labour Ind 27(3):232-248

Huws U, Spencer NH, Joyce S (2016) Crowd work in Europe: preliminary results from a survey in the UK, Sweden, Germany, Austria and the Netherlands. FEPS Studies. http://www.feps-europe.eu/ assets/39aad271-85ff-457c-8b23-b30d82bb808f/crowd-work-in-europe-draft-report-last-versi onpdf.pdf. Accessed 22 Dec 2019

Jaccard J, Wan CK (1996) LISREL approaches to interaction effects in multiple regression. Sage, New York

Jeng MY, Yeh TM (2016) The effect of consumer values on the brand position of green restaurants by means-end chain and laddering interviews. Serv Bus 10(1):223-238

Joo J, Shin MM (2020) Resolving the tension between full utilization of contact tracing app services and user stress as an effort to control the COVID-19 pandemic. Serv Bus (in press)

Jöreskog K (1971) Statistical analysis of sets of congeneric tests. Psychometrika 36:109-133

Jöreskog K, Sörbom D (1993) LISREL 8: structural equation modeling with the SIMPLIS command language. Scientific Software International, Chicago

Ju Y, Back KJ, Choi Y, Lee JS (2019) Exploring Airbnb service quality attributes and their asymmetric effects on customer satisfaction. Int J Hosp Manag 77:342-352

Just Eat (2019) El Gastrómetro: ¿qué, cuándo, dónde y cómo pide la gente comida a domicilio? Juest Eat. https://www.just-eat.es/blog/estamos-on-fire/el-gastrometro-que-cuando-donde-y-como-pidela-gente-comida-a-domicilio. Accessed 12 Dec 2019

Kaine S, Josserand E (2019) The organisation and experience of work in the gig economy. J Ind Relat 61(4):479-501

Kang J, Liu C, Kim SH (2013) Environmentally sustainable textile and apparel consumption: the role of consumer knowledge, perceived consumer effectiveness and perceived personal relevance. Int $\mathrm{J}$ Consum Stud 37(4):442-452

Kim D, Jang SS (2019) The psychological and motivational aspects of restaurant experience sharing behavior on social networking sites. Serv Bus 13(1):25-49

Kim GS, Lee GY, Park K (2010) A cross-national investigation on how ethical consumers build loyalty toward fair trade brands. J Bus Ethics 96(4):589-611

Kim M, Kim JH, Lennon SJ (2006) Online service attributes available on apparel retail web sites: an ESQUAL approach. Manage Serv Qual 16(1):51-77

Lee SW, Sung HJ, Jeon HM (2019) Determinants of continuous intention on food delivery apps: extending UTAUT2 with information quality. Sustainability 11(11):3141

Lee SM, Lee D (2020) "Untact": a new customer service strategy in the digital age. Serv Bus 14(1):1-22

Lien CH, Cao Y, Zhou X (2017) Service quality, satisfaction, stickiness, and usage intentions: an exploratory evaluation in the context of WeChat services. Comput Hum Behav 68:403-410

Loiacono ET, Watson RT, Goodhue DL (2002) WebQual: a measure of website quality. In: Evans K, Scheer L (eds) Marketing educators' conference: marketing theory and applications, vol 13. American Marketing Association, Chicago, pp 432-437

Lonner WJ, Berry JW (1986) Field methods in cross-cultural research. Sage, London

Marimon F, Cristóbal E (2012) La influencia de la calidad percibida en el sector de la distribución alimentaria por Internet: perspectiva multidimensional aplicada a un supermercado online. Rev Est Empr 1:131-148

Mehmood SM, Najmi A (2017) Understanding the impact of service convenience on customer satisfaction in home delivery: evidence from Pakistan. Inter J Electron Custom Relat Manage 11(1):23-43

Mohamed N, Hussein R, Zamzuri NHA, Haghshenas H (2014) Insights into individual's online shopping continuance intention. Ind Manage Data Syst 114(9):1453-1476

Moore G (2004) The fair trade movement: parameters, issues and future research. J Bus Ethics 53(1-2):73-86

Mulcahy D (2016) The gig economy: the complete guide to getting better work, taking more time off, and financing the life you want. Amacom, New York 
Nickols SY, Nielsen RB (2011) So many people are struggling: developing social empathy through a poverty simulation. J Poverty 15(1):22-42

Öberseder M, Schlegelmilch BB, Murphy PE (2013) CSR practices and consumer perceptions. J Bus Res 66(10):1839-1851

Parasuraman A (2000) Technology Readiness Index (TRI): a multiple item scale to measure readiness to embrace new technologies. J Serv Res 2(4):307-320

Parasuraman A, Zeithaml VA, Berry LL (1988) SERVQUAL: a multiple-item scale for measuring consumer perception. J Retail 64(1):12-40

Parasuraman A, Zeithaml VA, Malhotra A (2005) ES-QUAL: a multiple-item scale for assessing electronic service quality. J Serv Res 7(3):213-233

Pepper M, Jackson T, Uzzell D (2011) An examination of Christianity and socially conscious and frugal consumer behaviors. Environ Behav 43(2):274-290

Plewnia F, Guenther E (2018) Mapping the sharing economy for sustainability research. Manag Decis 56(3):570-583

Podsakoff PM, MacKenzie SB, Lee JY, Podsakoff NP (2003) Common method biases in behavioral research: a critical review of the literature and recommended remedies. J Appl Psychol 88(5):879-903

Rashid MS, Byun SE (2018) Are consumers willing to go the extra mile for fair trade products made in a developing country? A comparison with made in USA products at different prices. J Retail Consum Serv 41:201-210

Ray A, Dhir A, Bala PK, Kaur P (2019) Why do people use food delivery apps (FDA)? A uses and gratification theory perspective. J Retail Consum Serv 51:221-230

Roberts JA (1993) Sex differences in socially responsible consumers' behavior. Psychol Rep 73:139-148

Romera J, Semprún A (2018) Trabajo multiplica las inspecciones a Deliveroo y Glovo por sus autónomos. El Economista. https://www.eleconomista.es/empresas-finanzas/noticias/8914943/02/18/ Trabajo-acorrala-a-Deliveroo-y-Glovo-por-los-falsos-autonomos.html. Accessed 11 Feb 2020

Santos J (2003) E-service quality: a model of virtual service quality dimensions. Manag Serv Qual 13(3):233-246

Shobeiri S, Rajaobelina L, Durif F, Boivin C (2016) Experiential motivations of socially responsible consumption. Int J Market Res 58(1):119-139

Spurk D, Straub C (2020) Flexible employment relationships and careers in times of the COVID-19 pandemic. J Vocat Behav 119:103435

Statista (2019) Online food delivery. Statista. https://www.statista.com/outlook/374/100/online-fooddelivery/worldwide. Accessed 28 Dec 2019

Steenkamp JB, Geyskens I (2006) How country characteristics affect the perceived value of a website. J Mark 70(3):136-150

Steenkamp JB, Van Trijp HCM (1991) The use of LISREL in validating marketing constructs. Int J Res Mark 8(4):283-299

Stewart A, Stanford J (2017) Regulating work in the gig economy: what are the options? Econ Labour Relat Rev 28:420-437

Sultan F, Rohm AJ, Gao TT (2009) Factors influencing consumer acceptance of mobile marketing: a twocountry study of youth markets. J Interact Mark 23(4):308-320

Sweeney JC, Soutar GN (2001) Consumer perceived value: the development of a multiple item scale. J Retail 77(2):203-220

Szymanski DM, Hise RT (2000) E-satisfaction: an initial examination. J Retail 76(3):309-322

Tascioglu M, Eastman J, Bock D, Manrodt K, Shepherd CD (2019) The impact of retailers' sustainability and price on consumers' responses in different cultural contexts. Inter Rev Retail Distr Consum Res 29(4):430-455

Taylor M, Marsh G, Nicol D, Broadbent P (2017) Good work: the Taylor review of modern working practices. Department for Business, Energy and Industrial Strategy. https://www.gov.uk/government/ publications/good-work-the-taylor-review-of-modern-working-practices. Accessed 25 Jan 2020

Trocchia PJ, Janda S (2003) How do consumers evaluate internet retail service quality? J Serv Mark 17(3):243-253

Trudel R, Klein J, Sen S, Dawar N (2020) Feeling good by doing good: a selfish motivation for ethical choice. J Bus Ethics 166:39-49

Tsarenko Y, Strizhakova Y, Otnes CC (2019) Reclaiming the future: understanding customer forgiveness of service transgressions. J Serv Res 22(2):139-155 
Udo GJ, Bagchi KK, Kirs PJ (2010) An assessment of customers' e-service quality perception, satisfaction and intention. Int J Inf Manage 30(6):481-492

Ulusoy E (2016) Experiential responsible consumption. J Bus Res 69(1):284-297

Veen A, Barratt T, Goods C (2019) Platform-Capital's 'app-etite' for control: a labour process analysis of food-delivery work in Australia. Work Employ Soc 34(3):388-406

Webb DJ, Mohr LA, Harris KE (2008) A re-examination of socially responsible consumption and its measurement. J Bus Res 61(2):91-98

Wesley SC, Lee MY, Kim EY (2012) The role of perceived consumer effectiveness and motivational attitude on socially responsible purchasing behavior in South Korea. J Global Mark 25(1):29-44

Wolfinbarger M, Gilly MC (2003) eTailQ: dimensionalizing, measuring and predicting etail quality. J Retail 79(3):183-198

Wood AJ, Graham M, Lehdonvirta V, Hjorth I (2019) Good gig, bad gig: autonomy and algorithmic control in the global gig economy. Work Employ Soc 33(1):56-75

Yeo VCS, Goh SK, Rezaei S (2017) Consumer experiences, attitude and behavioral intention toward online food delivery (OFD) services. J Retail Consum Serv 35:150-162

Yoo B, Donthu N (2001) Developing and validating a multidimensional consumer-based brand equity scale. J Bus Res 52(1):1-14

Zeithaml VA (2002) Service excellence in electronic channels. Manag Serv Qual 12(3):135-139

Zeithaml VA, Berry LL, Parasuraman A (1996) The behavioral consequences of service quality. J Mark 60(2):31-46

Zhang X, Prybutok VR (2005) A consumer perspective of e-service quality. IEEE Trans Eng Manage 52(4):461-477

Zhang H, Wang Z, Chen S, Guo C (2019) Product recommendation in online social networking communities: an empirical study of antecedents and a mediator. Inf Manag 56(2):185-195

Publisher's Note Springer Nature remains neutral with regard to jurisdictional claims in published maps and institutional affiliations. 